\title{
ANALISIS KUAT LENTUR BALOK LAMINASI LENGKUNG DENGAN PEREKAT EPOXY
}

\author{
Affan Annur Annaafi ${ }^{1)}$, Iskandar Yasin ${ }^{2)}$, M. Afif Shulhan ${ }^{3)}$ \\ ${ }^{1}$ Program Studi Teknik Sipil, Fakultas Teknik, Universitas Sarjanawiyata Tamansiswa Yogyakarta, \\ Jln. Miliran No.16, Yogyakarta, 55165 \\ E-mail : affanannaafi66@gmail.com \\ ${ }^{2}$ Program Studi Teknik Sipil, Fakultas Teknik, Universitas Sarjanawiyata Tamansiswa Yogyakarta \\ Email : iskandartamansiswa@gmail.com \\ ${ }^{3}$ Program Studi Teknik Sipil, Fakultas Teknik, Universitas Sarjanawiyata Tamansiswa Yogyakarta \\ Email : $\underline{\text { m.afif.shulhan@gmail.com }}$
}

\begin{abstract}
Very large needs for woodhave an impact on the availability of wood which is decreasing every year, due to exploitation carried out on a large scale. Therefore it's developed as a structure laminated components made by gluing several layers of wood or commonly called laminated beams or Glulam (Glued Laminated). This study used the experimental method by flexural test with one point loading. The dimensions of the object are $100 \mathrm{~cm}$ long, $2 \mathrm{~cm}$ wide, and by heigth variation $10 \mathrm{~cm}, 20 \mathrm{~cm}, 30 \mathrm{~cm}$. Each variation used 3 specimens so there are 9 specimens. This specimens using epoxy adhesive. The results of the study showed that the flexural strength of the curved laminated beam with epoxy adhesive on an average load of $85.45 \mathrm{Kg}$ and an average deflection of $23,510 \mathrm{~mm}$. The result of laminated beam have maximum strength of $128.9 \mathrm{Kg}$ with $17.27 \mathrm{~mm}$ deflection.

Key words: Curved laminated beam, Flexural strength, deflection
\end{abstract}

\begin{abstract}
Abstrak
Kebutuhan kayu yang sangat besar berdampak pada ketersediaan kayu yang semakin berkurang setiap tahunnya akibat eksploitasi yang dilakukan secara besar-besaran. Maka dari itu di kembangkanlah bentuk struktur komponen kayu laminasi yang dibuat melalui perekatan beberapa lapis kayu atau biasa disebut dengan balok laminasi atau Glulam (Glued Laminated). Penelitian ini menggunakan metode eksperimen dengan melakukan uji lentur dengan beban satu titik. Dimensi benda uji balok laminasi lengkung memiliki panjang $100 \mathrm{~cm}$, lebar $2 \mathrm{~cm}$ dan variasi tinggi $10 \mathrm{~cm}, 20 \mathrm{~cm}, 30 \mathrm{~cm}$. Masing-masing variasi sebanyak 3 benda uji sehingga ada 9 benda uji. Balok laminasi menggunakan perekat epoxy. Hasil penelitian menunjukan bahwa kuat lentur balok laminasi lengkung dengan perekat epoxy mampu menahan beban rata-rata sebesar 85,45 $\mathrm{Kg}$ dan lendutan rata-rata $23,510 \mathrm{~mm}$. Hasil pengujian lenturbalok laminasi mempunyai kekuatan maksimum $128,9 \mathrm{~kg}$ dengan lendutan 17,27 mm.

Kata kunci : Balok laminasi lengkung, kuat lentur, lendutan
\end{abstract}

\section{PENDAHULUAN}

Kebutuhan kayu yang sangat besar berdampak pada ketersediaan kayu yang semakin berkurang setiap tahunnya akibat eksploitasi yang dilakukan secara besarbesaran (Handayani, 2016).Sehingga di kembangkanlah bentuk struktur bukan kayu utuh melainkan kompone laminasi yang dibuat melalui perekatan atau biasa disebut dengan balok laminasi atau Glulam (Glued Laminated).Laminasi (glulam) adalah gabungan dari satu macam bahan ataupun lebih dimana bahan tersebut dibuat menjadi lapisan-lapisan yang relatif tipis yang direkatkan satu sama lain (Handayani, 2016). Balok laminasi terbuat dari dua atau lebih kayu gergajian yang direkat dengan arah serat sejajar satu sama lain berbentuk lurus atau lengkung tergantung peruntukannya (Moody et al,1999)

Berkaitan dengan hal tersebut pembuatan balok laminasi lengkungperlu diteliti tentang kuat lenturnyaberdasarkan perbandingan panjang penampang dan kelengkungan balok.

Tujuan penelitian

1. Untuk mengetahui berapa besar beban dan lendutan balok kayu laminasi lengkung menggunakan perekat epoxy.

2. Untuk menegetahui apakah beban yang dihasilkan sesuai standar SNI- 7973-2013 (Spesifikasi desain konstruksi kayu).
3. Untuk mengetahui pola kekuatan dan lendutan dari perbandingan kekuatan dan variasi dimensi benda uji.

4. Untuk mengetahui perilaku balok dari pengujian perkuatan balok kayu laminasi menggunakan perekat epoxy.

Batasan penelitian

Adapun dalam penulisan laporan ini batasan-batasan masalahnya sebagai berikut :

1. Penelitian ini hanya meninjau pengujian lentur balok lengkung kayu laminasi dengan perekat expoxy.

2. Jenis kayu laminasi sengon (triplek sengon).

3. Sumber material dari kota Klaten.

\section{TINJAUAN PUSTAKA}

Structural glued laminated timber (Laminasi) adalah teknologi pengolahan kayu yang sudah dikenal sejak dulu. Laminasi adalah penyatuan beberapa lapis kayu dengan lem pada kedua sisinya kemudian diberi tekanan. Proses pengeleman ini dilakukan mengikuti arah panjang kayu.

\section{Penelitian Sebelumnya}

Yasin, $d k k$ 2015. Bambu laminasi sebagai aternatif bahan bangunan pengganti kayu, mempunyai prospek yang bagus dalam pemenuhan kebutuhan konstruksi. Tanaman bambu cepat tumbuh, tidak memerlukan perlakuan khusus ketika ditanam dan mampu tumbuh diberbagai kondisi lahan. 
Yasin, 2018. Analisis Mikroskopis Pengaruh Tekanan Kempa Pada Balok Bambu Laminasi. Dari hasil penelitian didapatkan bahwa pengempaan dengan besaran 1,5 MPa sampai dengan 2,5 MPa tidak mempengaruhi besarnya kadar air dan kerapatan.

Handayani, 2016. Melakukan analisis pengujian struktur balok laminasi kayu sengin dan kayu kelapa. Benda uji balok dimensi $5 \mathrm{~cm} \times 5 \mathrm{~cm} \times 76 \mathrm{~cm}$ dengan variasi perbedaan perekat Epoxy dan Aibon. Variasi lain adalah posisi kayu laminasi (Sengon-Glugu-Sengon dan Glugu-Sengon-Glugu). Hasil penelitian memberikan penjelasan bahwa teknologi laminasi dengan penggunaan lem Epoxy pada perkuatan balok laminasi Sengon-Glugu dengan variasi EP-S (bahan perekat lem epoxy dan letak kayu sengon di dalam) mampu memberikan peningkatan kuat lentur yang cukup tinggi sebesar 59,72\%.

Aji $d k k$, 2013. Meneliti karakteristik balok lengkung laminasi dari kayu mahoni (Swietenia macrophylla) dan ketapang (Terminalia catappa).Tujuan dari peneliti adalah untuk mengetahui kekuatan balok laminasi lengkung yang dapat digunakan sebagai kayu bangunan. Perlakuan eksperimen dilakukan dengan membuat variasi susunan kayu mahoni dan kayu ketapang. Obyek penelitian ini adalah kayu mahoni dan kayu ketapang yang dibuat balok lengkung laminasi. Balok lengkung laminasi yang telah dibuat memiliki ukuran panjang, lebar, dan tebal secara berturut-turut $300 \mathrm{~cm}, 12$ $\mathrm{cm}$, dan $6 \mathrm{~cm}$. Balok laminasi terdiri dari 6 lapis papan kayu. Dengan adanya variasi susunan kayu ketapangketapang (KK) dan mahoni ketapang (MK) dilakukan perbandingan kekuatan dari kedua variasitersebut dan dikombinasikan dengan tambahan keawetan dari 2 benda uji yang diteliti.

\section{METODE PENELITIAN}

Metode yang diterapkan dalam penelitian ini adalah metode eksperimen, yaitu penelitian yang bertujuan untuk menyelidiki kekuatan dari benda uji perbandingan $\mathrm{H} / \mathrm{L} 0,1$ $\mathrm{cm}, 0,2 \mathrm{~cm}$ dan $0,3 \mathrm{~cm}$ dan kadar air dari kayu asal untuk benda uji. Pengujian yang dilakukan dalam penelitian ini yaitu pengujian kuat lentur balok laminasi lengkung, kadar air dan berat jenis. Bahan penelitian menggunakan triplek kayu sengon.

Dimensi benda uji yang digunakan dalam penelitian ini berupa balok laminasi lengkung dengan panjang $100 \mathrm{~cm}$, variasi tinggi $10 \mathrm{~cm}, 20 \mathrm{~cm}$, dan $30 \mathrm{~cm}$ dengan masing-masing berjumlah 3 benda uji. Tiap benda uji terdiri dari 10 lapis triplekkayu sengon yang direkatkan dengan lem epoxy. Pengujian lentur menggunakan mesin UTM dengan satu pembebanan di tengah. Dimensi benda uji kadar air berukuran $5 \times 5 \times 5 \mathrm{~cm}$.

Tabel 1.Variasi benda uji

\begin{tabular}{ccccc}
\hline No & Benda uji & $\begin{array}{c}\text { Lebar } \\
\text { L }(\mathrm{cm})\end{array}$ & $\begin{array}{c}\text { Tinggi } \\
\text { lengkung } \\
\mathrm{H}(\mathrm{cm})\end{array}$ & $\begin{array}{c}\text { Perbandingan } \\
\mathrm{H} / \mathrm{L}\end{array}$ \\
\hline 1 & BLK (1-3) & 100 & 10 & 0,1 \\
2 & BLK (4-6) & 100 & 20 & 0,2 \\
3 & BLK (7-9) & 100 & 30 & 0,3 \\
\hline
\end{tabular}

\section{Bahan dan Alat}

Bahan yang digunakan dalam penelitian ini adalah sebagai berikut :

1. Kayu laminasi dari triplek kayu sengon dengan ukuran $0,3 \times 2 \times 120 \mathrm{~cm}$ dengan ketebalan $3 \mathrm{~mm}$ (90 buah).

2. Perekat Epoxy.Perekat epoxy merupakan produk sintetik termoset dari resin poliepoksi dengan pengeras (hardener). Resin dicampur dengan hardener sampai mengental berwarna keputihan.

Alat yang dipakai untuk membuat benda uji antara lain :

1. Alat pemotong kayu (gergaji) untuk pemotong kayu atau membelah kayu benda uji.

2. Meteran digunakan untuk mengecek ukuran bahan penelitian, utamanya agar ukurannya sesuai dengan yang telah direncanakan.

3. Alat pasah penghalus kayu digunakan untuk membuat permukaan benda yang kasar menjadi lebih halus.

4. Kawat bendrat digunakan untuk mengikat dalam proses pengeleman dan proses pelengkungan benda uji.

5. Klem Berfungsi sebagai penahan atau mengklem sambungan benda uji yang sudah diolesi perekat supaya tidak berubah posisi.

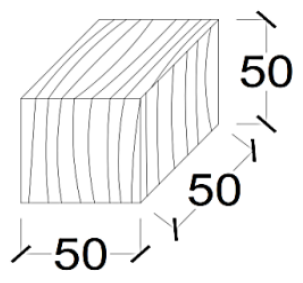

Gambar 1.benda uji kadar air kayu sengon

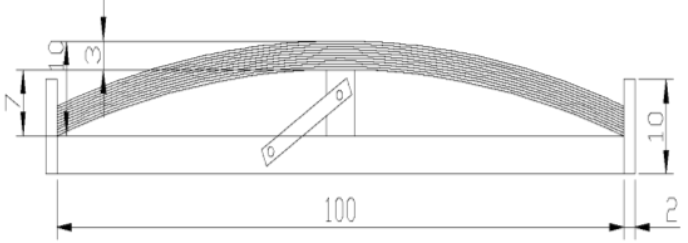

Gambar 2.Gambar skema benda uji (BLK 1-3)

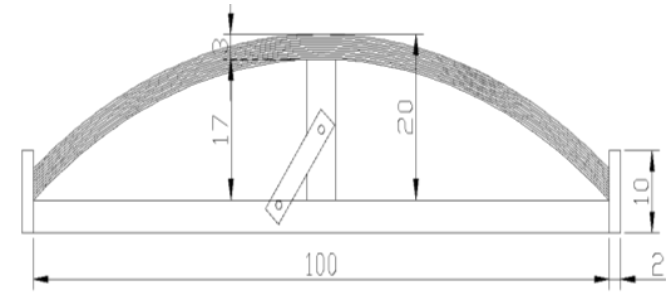

Gambar 3.Gambar skema benda uji (BLK 4-6)

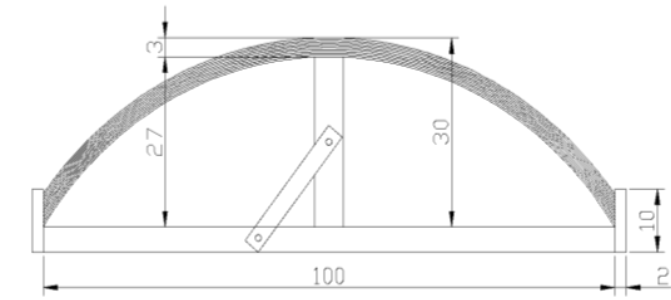

Gambar 4.Gambar skema alat benda uji (BLK 7-9) 


\section{HASIL DAN PEMBAHASAN}

\section{Pengujian Kadar Air Dan Berat Jenis}

Pengujian ini dilakukan untuk mengetahui kadar air dan berat jenis kayu sengon digunakan sebagai acuan untuk penelitian ini dapat dilihat tabel dibawah ini:

Tabel 2.Pengujian pendahuluan kadar air dan berat jenis

\begin{tabular}{ccccc}
\hline Kode & $\begin{array}{c}\text { Kadar } \\
\text { Air }(\%)\end{array}$ & $\begin{array}{c}\text { Kadar Air } \\
\text { Rata-Rata }\end{array}$ & $\begin{array}{c}\text { Berat } \\
\text { Jenis }\end{array}$ & $\begin{array}{c}\text { Berat } \\
\text { Jenis } \\
\text { Rata- } \\
\text { rata }\end{array}$ \\
\hline B-1 & 18.74 & & 0.50 & \\
B-2 & 16.84 & & 0.45 & \\
B-3 & 15.81 & 17.23 & 0.46 & 0.48 \\
B-4 & 17.41 & & 0.48 & \\
B-5 & 17.35 & & 0.49 & \\
\hline
\end{tabular}

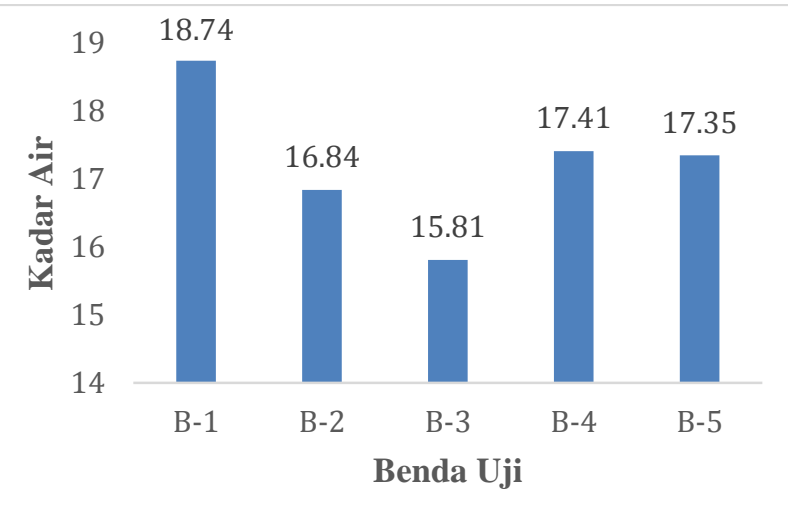

Gambar 5. Grafik Hasil Uji Kadar Air Kayu Sengon

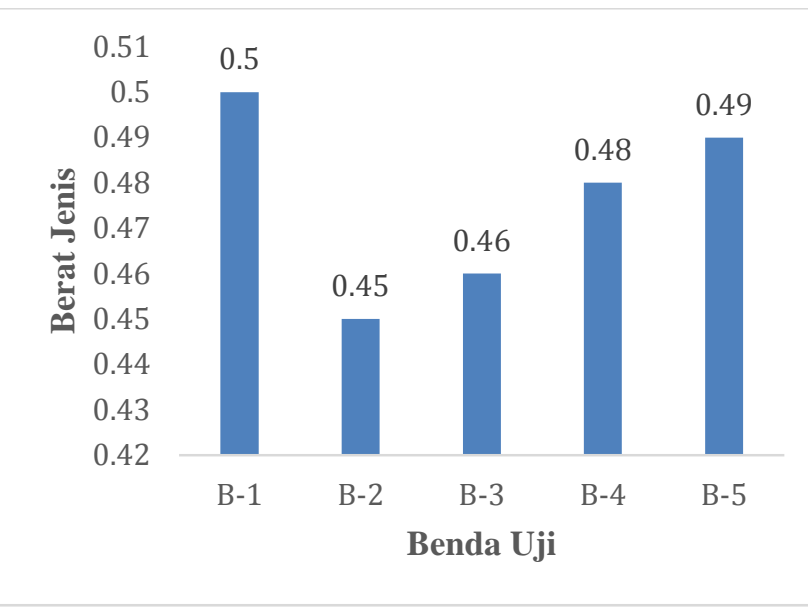

Gambar 6. Grafik Hasil Uji Berat Jenis Kayu Sengon

Hasil uji kadar air kayu utuh pada benda uji B-3 mencapai paling rendah sebesar 15.88, untuk berat jenisnya mencapai 0.46. Sementara kadar air paling tinggi adalah pada benda uji kode B-1 mencapai sebesar 18.43, untuk berat jenisnya sebesar 0.50 . Kadar air rata-rata sebesar $17.23 \%$, berdasar mutu kayu termasuk mutu B. Berat jenis rata-rata sebesar 0.48 , berdasar kelas kuat kayu termasuk kelas III.

\section{Pola kegagalan balok laminasi lengkung}

Dari hasil pengujian pola kegagalan atau kerusakan balok kayu laminasi triplek dengan perekat epoxy dapat dilihat pada gambar dibawah ini :

a. Pola kegagalan BLK (1-3)

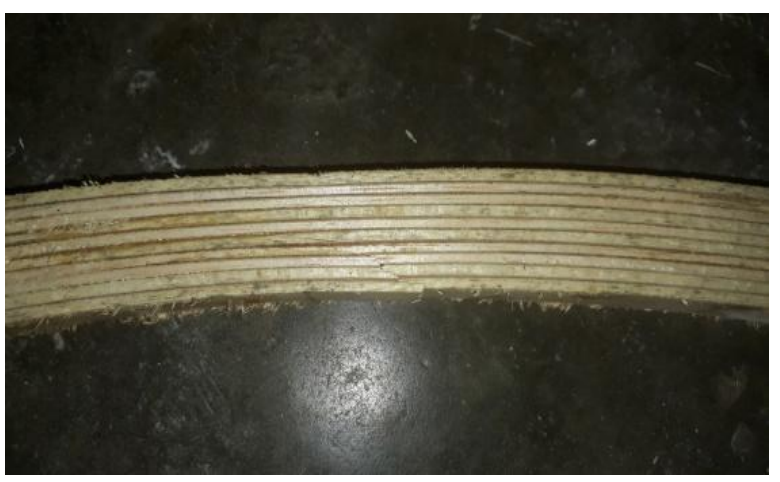

Gambar 7.Pola kegagalan BLK 3

Pola kegagalan yang dialami BLK 3 yaitu diawali dengan triplek yang direkatkan mulai retak diawal pada lapisan 5, selajutnya triplek yang direkatkan mulai retak dari lapisan 5 sampai kebawah dan untuk BLK 1 dan 2 tidak ada keretakan yang terjadi balok melengkung kebawah saat ditekan dan kembali seperti semula.

\section{b. Pola kegagalan BLK (4-6)}

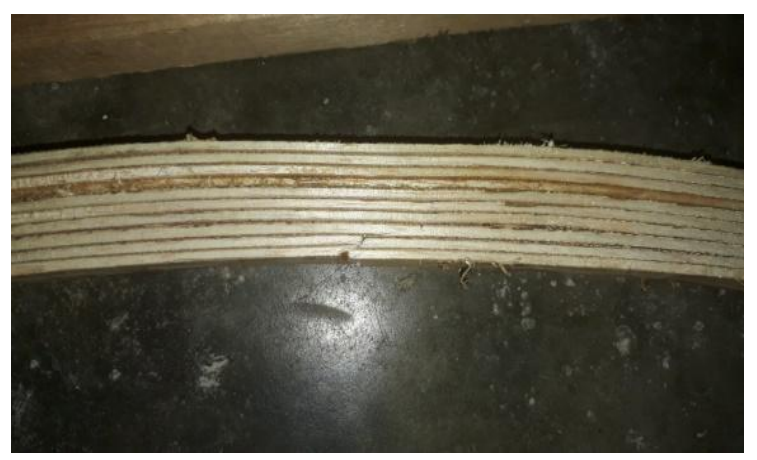

Gambar 8.Pola kegagalan BLK 4

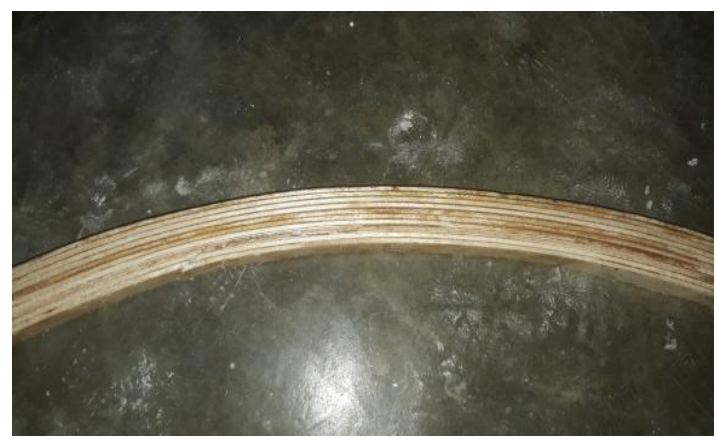

Gambar 9. Pola kegagalan BLK 5 


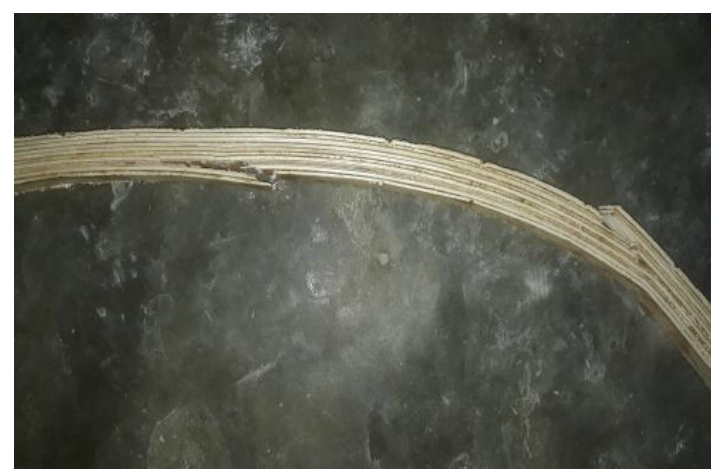

Gambar 10.Pola kegagalan BLK 6

Pola kegagalan yang terjadi pada BLK 4 yaitu diawali dengan triplek yang direkatkan retak pada lapisan 4, selajutnya triplek mulai retak dengan pola sejajar pada lapisan 4 dan lapisan bawahnya retak pola tegak kebawah. Pola kegagalan yang dialami BLK 5 yaitu diawali dengan triplek yang direkatkan mulai retak pada lapisan 3, selajutnya triplek mulai retak dengan pola tegak kebawah dari lapisan 3 kebawah.

Pola kegagalan yang dialami BLK 6 yaitu diawali dengan triplek retak pada lapisan 3, selajutnya triplek mulai retak dengan pola sejajar pada lapisan 3 dan lapisan bawahnya retak pola tegak kebawah.

\section{c. Pola kegagalan BLK (7-9)}

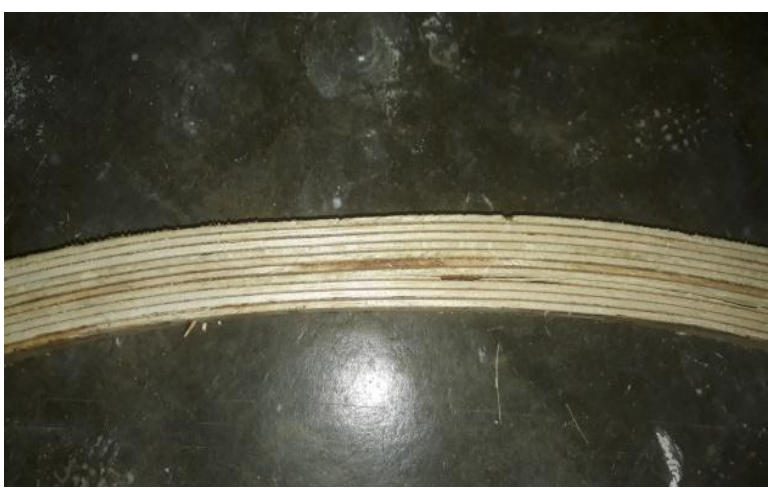

Gambar 11.Pola kegagalan BLK 7

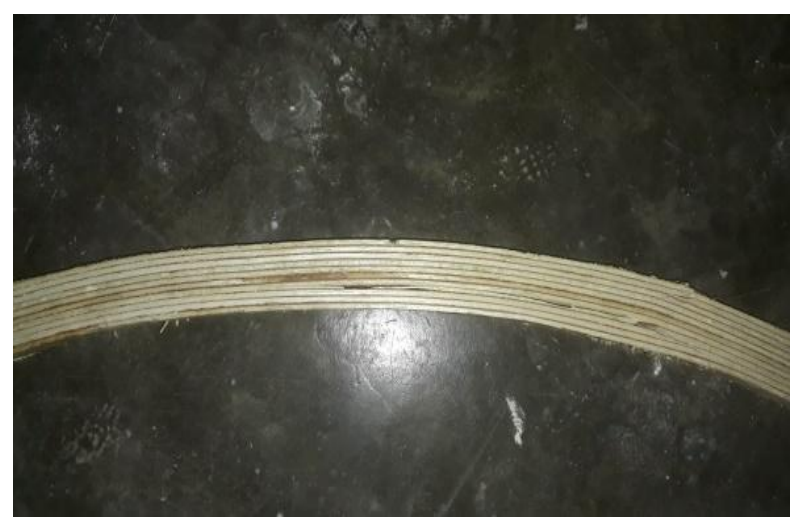

Gambar 12.Pola kegagalan BLK 8

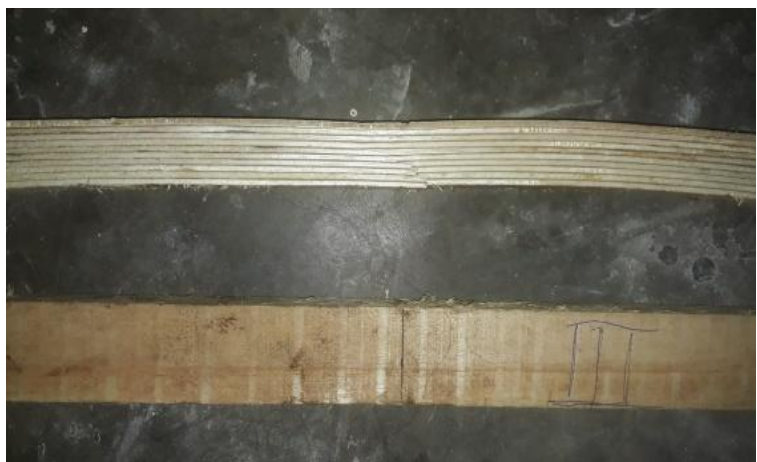

Gambar 13.Pola kegagalan BLK 9

Pola kegagalan yang dialami BLK 7 yaitu diawali dengan triplek yang direkatkan mulai retak pada lapisan 5, selajutnya triplek mulai retak dengan pola sejajar pada lapisan 5 dan 4 bergerak dengan pola tegak kebawah diikuti dengan keretakan dilapisan atas 2 lapisan dari atas. Pola kegagalan yang dialami BLK 8 yaitu diawali dengan triplek yang direkatkan mulai retak pada lapisan 4, selajutnya triplek mulai retak dengan pola sejajar pada lapisan 4 bergerak kelapisan bawahnya diikuti dengan keretakanlapisan 8. Pola kegagalan yang dialami BLK 9 yaitu diawali dengan triplek yang direkatkan mulai retak pada lapisan 4, selajutnya triplek mulai retak dengan pola sejajar pada lapisan 4 diikuti pada lapisan kelima.

Pola kerusakan mayoritas benda uji pada lapisan 5, 4, dan 3 menuju ke bawah. Sedangkan pada lapisan paling atas tidak terjadi kerusakan. Pada BLK 1 dan BLK 2 tidak terjadi kerusakan karena kelengkungan balok $10 \mathrm{~cm}$ dan beban juga kecil sehingga mampu menahan beban sampai posisi lengkungan menyentuh dasar sejajar dengan tumpuan.

\section{Beban dan Lendutan Balok Kayu Laminasi}

Dari data hasil uji lentur balok dapat dilihat pada grafik sebagai berikut :

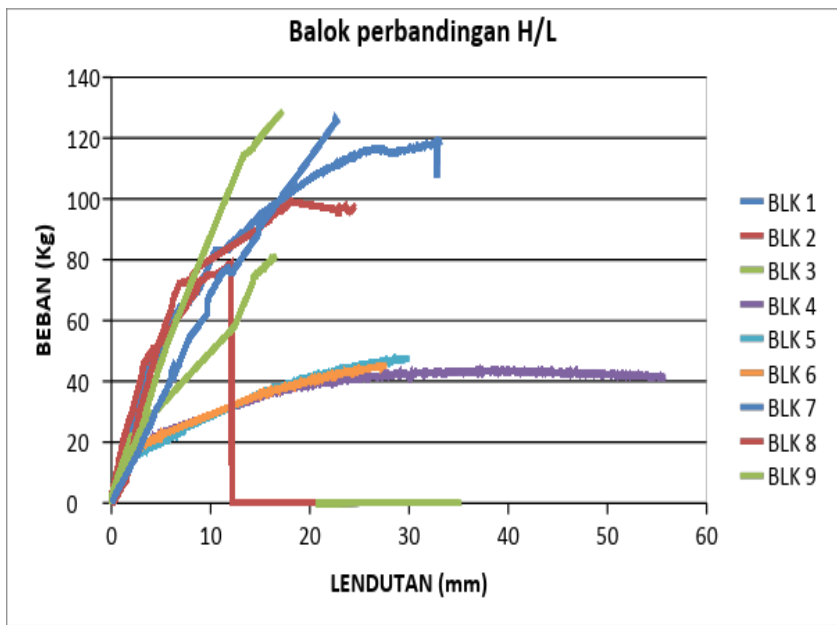

Gambar 14.Grafik Uji Lentur Balok Laminasi

Berdasarkan grafik di atas beban berada diantara $40 \mathrm{Kg}$ sampai $130 \mathrm{Kg}$. Beban maksimum sebesar 128,9 kg pada benda uji BLK-8 yaitu pada benda uji kelengkungan 30 cm.Beban minimal diperoleh sebesar 43,66 kg pada benda uji BLK-1 yaitu kelengkungan $10 \mathrm{~cm}$. 


\begin{tabular}{cccccc}
\multicolumn{6}{c}{ Tabel 3.Tabel hasil pengujian kuat lentur. } \\
\hline No & $\begin{array}{c}\text { Benda } \\
\text { Uji }\end{array}$ & $\begin{array}{c}\text { Beban } \\
(\mathrm{Kg})\end{array}$ & $\begin{array}{c}\text { Lendutan } \\
(\mathrm{mm})\end{array}$ & $\begin{array}{c}\text { Rata- } \\
\text { Rata } \\
\text { Beban } \\
(\mathrm{Kg})\end{array}$ & $\begin{array}{c}\text { Rata- } \\
\text { Rata } \\
\text { Lendutan } \\
(\mathrm{mm})\end{array}$ \\
\hline 1 & BLK-1 & 43.66 & 40.03 & & \\
2 & BLK-2 & 47.43 & 29.54 & 43.35 & 32.28 \\
3 & BLK-3 & 44.98 & 27.27 & & \\
\hline 4 & BLK-4 & 118.93 & 32.73 & & \\
5 & BLK-5 & 78.66 & 12.06 & 92.96 & 19.4 \\
6 & BLK-6 & 81.3 & 13.41 & & \\
\hline 7 & BLK-7 & 98.98 & 16.66 & & \\
8 & BLK-8 & 128.9 & 17.27 & 118.05 & 18.83 \\
9 & BLK-9 & 126.27 & 22.57 & & \\
\hline
\end{tabular}

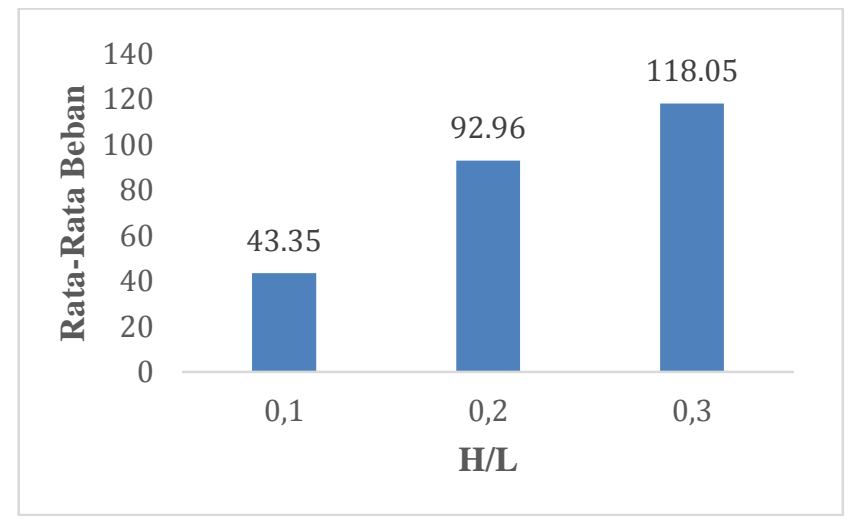

Gambar 15. Grafik Rata-Rata Beban

Dari tabel dan grafik diatas dapat di ketahui di peroleh beban rata-rata keseluruhan $85,45 \mathrm{~kg}$.

Kenaikan beban lentur dari benda uji kelengkungan $10 \mathrm{~cm}$ terhadap benda uji kelengkungan $20 \mathrm{~cm}$ sebesar $144.44 \%$. Kenaikan beban lentur dari benda uji kelengkungan $20 \mathrm{~cm}$ terhadap benda uji kelengkungan $30 \mathrm{~cm}$ sebesar $27 \%$. Peningkatan yang cukup besar pada kelengkungan $20 \mathrm{~cm}$. Dan untuk hasil lendutan pada pengujian ini di peroleh ledutan maksimum pada benda uji BLK-1 sebesar 40,03 $\mathrm{mm}$ yaitu pada kelengkungan $10 \mathrm{~cm}$. Lendutan minimum di peroleh hasil sebesar 12,06 mm pada benda uji BLK-5 yaitu pada kelengkungan $20 \mathrm{~cm}$. Lendutan rata-rata keseluruhan benda uji sebesar 23,51 mm.

Semakin tinggi kelengkungan semakin besar beban yang mampu ditahan dan semakin kecil lendutannya.

\section{PENUTUP}

\section{Kesimpulan}

Dari data hasil eksperimen yang sudah dilakukan disimpulkan bahwa :

1. Kuat lentur balok laminasi lengkung dengan perekat epoxy perkuatan mampu menahan beban rata-rata sebesar $85,45 \mathrm{~kg}$ dan lendutan rata-rata $23,510 \mathrm{~mm}$.
2. Secara keseluruhan beban yang dihasilkan dari pengujian ini memenuhi persyaratan untuk bahan struktural (SNI-7973-2013).

3. Dari hasil pengujian dapat disimpulkan bahwa semakin tinggi kelengkungan semakin besar beban yang diperoleh sedangkan semakin pendek kelengkungannya semakin besar lendutan yang diperoleh.

4. Pola dari setiap benda uji mengalami kerusakan atau runtuh retak yang dimulai pada lapisan kisaran 5, 4, dan 3 dan menuju kelapisan paling bawah dari retak sejajar maupun tegak.

\section{Saran}

1. Diharapkan untuk penelitian selanjutnya peneliti dapat menggunakan variasi dimensi yang berbeda dari penelitian ini.

2. Diharapkan penelitian selanjutnya peneliti disarankan agar menggunakan perekat dengan jenis lain dan kayu jenis lain.

3. Diharapkan penelitian yang selanjutnya disarankan peneliti menggunakan perekat dan sekrup atau baut sebagai peningkat perkuatan.

4. Penelitian berikutnya diharapkan penambahan variasi kelengkungan sehingga diperoleh kelengkungan yang optimum dalam menahan beban lentur.

\section{DAFTAR PUSTAKA}

Bambang dan Adhi, (2010). Study on Load Carrying Capacity and Stiffness of Curved Glulam Beam. Department of Civil Engineering Parahyangan Catholic University Bandung, Indonesia.

Djoko Purwanto, (2010). Balok Laminasi Dari Kayu Kelapa (Cocos Nucifera L). Jurnal Riset Industri Hasil Hutan. Peneliti Baristand Industri Banjarbaru.

Handayani Sri, (2016). Analisis Pengujian Struktur Balok Laminasi Kayu Sengon Dan Kayu Kelapa. Jurnal Teknik Sipil. Universitas Negeri semarang.

Nugroho, Hardian Dwi,(2017). Karakteristik Balok Lengkung Laminasi Dari Kayu Mahoni (Swietenia Macrophylla) Dan Ketapang(Terminalia Catappa). Tugas Akhir. Fakultas Kehutanan Institut Pertanian Bogor.

Moody RC, Hernandez R, Liu JY, (1999).Glued Structural Members. Di dalam : Wood Handbook, Woodas an Engineering Material. Madison, WI : USDA, Forest Product Service, Forest Laboratory. HIm 19.1-19.4

Ratna Widyawati, (2010). Kekuatan Sambungan Tegak (Butt Joint) Struktur balok laminasi (Glulam Beams) dari kayu lokal. Jurnal Rekayasa. Jurusan Teknik Sipil. Universitas Lampung.

SNI 7973 : 2013. Spesifikasi desain untuk konstruksi kayu. Sutyas Aji, Darmawan L(2013). Alternatif Sambungan Finger Joint Pada Balok Kayu Terhadap Pengujian Kuat Lentur. Jurusan Teknik Sipil. Universitas Kristen Immanuel Yogyakarta.

Wicaksono, (2017). Analisis Perkuatan Lentur Balok Kayu Sengon Dengan Sistem Komposit Balok Sandwich (Lamina Dan plant). Departemen Teknik Sipil dan Lingkungan. Universitas Gadjah Mada. 
Yasin, Iskandar., Priyosulistyo, Henricus., Siswosukarto, Suprapto., Saputra, Ashar., (2015), The Effect of Variable Lateral Stress of Laminated Bambu with Artificially Dent Surface on Mechanical Properties, International Journal of Civil and Structural Engineering (IJCSE), ISSN : 2372-3971, Issue 02, Volume 2, pp. 80-83.

Yasin, Iskandar, (2018), Analisis Mikroskopis Pengaruh Tekanan Kempa Pada Balok Bambu Laminasi, Jurnal Renovasi, Rekayasa dan Inovasi Teknik Sipil, Volume 3, nomor 1, 2018 